\title{
SPIRAMYCIN IN THE TREATMENT OF POSTERIOR UVEITIS
}

\author{
BY \\ J. M. HEATON \\ Institute of Ophthalmology, London
}

MosT ophthalmologists would agree that the treatment of posterior uveitis of possible toxoplasmic origin is unsatisfactory. Perhaps the most important advance in its treatment in recent years has been the introduction of systemic steroid therapy, but although this can often suppress an attack it does not eliminate the causal pathogen. Pyrimethamine (Daraprim) and sulphonamide in combination are sometimes given as they possess an antitoxoplasmic effect in experimental infections; but although some, for example Ryan, Hart, Culligan, Gunkel, Jacobs, and Cook (1954), Perkins, Smith, and Schofield (1956), have reported success with these drugs, others (Hogan, 1958) have found the results disappointing. Also the drugs possess serious toxic properties in the dose required to maintain adequate serum levels.

Therefore it was of considerable interest when Chodos and HabeggerChodos (1961) reported that they considered Spiramycin to be the treatment of choice in ocular toxoplasmosis. They had carried out a therapeutic trial over a period of a year on 67 patients with acutely active posterior retinochoroidal lesions. They used Spiramycin, a wide-spectrum antibiotic produced by a strain of Streptomyces, as it had been shown to be effective in animals experimentally infected with Toxoplasma gondii (Bogacz, 1954).

\section{Present Investigations}

In this paper we report on a clinical trial of Spiramycin in posterior uveitis done over a period of about a year and a half.

Material.-Thirty patients with posterior uveitis were included in the trial; their ages ranged from 18 to 58 years and there were sixteen men and fourteen women. In 23 cases there were one or more active foci of choroiditis, in five an area of juxtapapillary choroiditis, and in two no active focus could be seen because of density of the vitreous haze.

Method.-Every patient was examined and investigated in the routine manner of the Uveitis Clinic of the Institute of Ophthalmology, London (Perkins, 1961). Toxoplasmosis dye and complement-fixation tests were done just before and directly after the course of Spiramycin.

The dose of Spiramycin was $2 \mathrm{~g}$. daily for 6 weeks. The patients continued with any conventional medical treatment they were receiving. At the start of the trial every patient was given some kaolin mixture and warned that he might have transient diarrhoea.

* Received for publication, December 26, 1962. 
The patients were seen at 2-weekly intervals, when a further ophthalmic examination was carried out and any toxic effects were inquired for. After 6 weeks the drug was stopped and an assessment of progress made. Four categories were used: no change, improved, much improved, cleared. A case that was considered "cleared" had no flare or cells in the aqueous, no recent keratic precipitates, and no cells or exudate in the vitreous, and the choroidal lesion was flat, hard, and beginning to pigment. The assessment was made chiefly on these clinical signs and not on the visual acuity, as in some cases there was macular damage from previous attacks.

Finally, the hospital notes of every patient were examined at the end of the trial to assess the long-term results of the course of Spiramycin; the length of this follow-up varied from 1 to 18 months according to the date of starting the course.

\section{Results of Treatment}

The results of the 6 weeks' treatment with Spiramycin are given in Table I.

TABLE I

RESULTS OF TREATMENT IN THIRTY CASES

\begin{tabular}{|c|c|c|c|c|c|}
\hline Age & Sex & Diagnosis & $\begin{array}{c}\text { Duration of Disease } \\
\text { before Treatment } \\
\text { (wks) }\end{array}$ & $\begin{array}{l}\text { Results of } \\
\text { Treatment }\end{array}$ & Relapse \\
\hline $\begin{array}{l}29 \\
23 \\
55 \\
24 \\
33 \\
22 \\
31 \\
33 \\
37 \\
20 \\
35 \\
37 \\
23 \\
58 \\
25 \\
22 \\
30 \\
34 \\
26 \\
45 \\
18 \\
57 \\
42 \\
47 \\
41 \\
50 \\
24 \\
39 \\
54 \\
29\end{array}$ & $\begin{array}{l}\mathbf{M} \\
\mathbf{M} \\
\mathbf{F} \\
\mathbf{F} \\
\mathbf{F} \\
\mathbf{M} \\
\mathbf{M} \\
\mathbf{M} \\
\mathbf{M} \\
\mathbf{M} \\
\mathbf{M} \\
\mathbf{M} \\
\mathbf{M} \\
\mathbf{F} \\
\mathbf{F} \\
\mathbf{M} \\
\mathbf{F} \\
\mathbf{M} \\
\mathbf{M} \\
\mathbf{F} \\
\mathbf{F} \\
\mathbf{F} \\
\mathbf{F} \\
\mathbf{F} \\
\mathbf{F} \\
\mathbf{M} \\
\mathbf{M} \\
\mathbf{F} \\
\mathbf{F}\end{array}$ & $\begin{array}{l}\text { Focal choroiditis } \\
\text { Focal choroiditis } \\
\text { Focal choroiditis } \\
\text { Juxta-papillary choroiditis } \\
\text { Focal choroiditis } \\
\text { Juxta-papillary choroiditis } \\
\text { Juxta-papillary choroiditis } \\
\text { Juxta-papillary choroiditis } \\
\text { Focal choroiditis } \\
\text { Focal choroiditis } \\
\text { Focal choroiditis } \\
\text { Focal choroiditis } \\
\text { Juxta-papillary choroiditis } \\
\text { Focal choroiditis } \\
\text { Focal choroiditis } \\
\text { Focal choroiditis } \\
\text { Focal choroiditis } \\
\text { Generalized uveitis } \\
\text { Focal choroiditis } \\
\text { Focal choroiditis } \\
\text { Focal choroiditis } \\
\text { Focal choroiditis } \\
\text { Focal choroiditis } \\
\text { Focal choroiditis } \\
\text { Focal choroiditis } \\
\text { Focal choroiditis } \\
\text { Focal choroiditis } \\
\text { Focal choroiditis } \\
\text { Peripheral choroiditis } \\
\text { Generalized uveitis }\end{array}$ & $\begin{array}{r}2 \\
2 \\
2 \\
2 \\
3 \\
3 \\
3 \\
3 \\
3 \\
3 \\
4 \\
4 \\
4 \\
4 \\
4 \\
4 \\
4 \\
6 \\
8 \\
8 \\
12 \\
16 \\
16 \\
26 \\
26 \\
52 \\
52 \\
52 \\
104 \\
208\end{array}$ & $\begin{array}{l}\text { Improved } \\
\text { Improved } \\
\text { Improved } \\
\text { No change } \\
\text { Cleared } \\
\text { Much improved } \\
\text { Improved* } \\
\text { No change } \\
\text { Much improved* } \\
\text { Cleared } \\
\text { Improved } \\
\text { Cleared } \\
\text { Improved } \\
\text { Much improved* } \\
\text { Improved } \\
\text { Much improved } \\
\text { Much improved } \\
\text { Improved } \\
\text { Improved } \\
\text { Much improved } \\
\text { Much improved* } \\
\text { No change } \\
\text { Improved } \\
\text { No change } \\
\text { Improved } \\
\text { Improved } \\
\text { No change } \\
\text { Improved } \\
\text { Improved* } \\
\text { Improved* }\end{array}$ & $\begin{array}{l}\text { None } \\
\text { None } \\
\text { Yes } \\
\text { None } \\
\text { None } \\
\text { None } \\
\text { None } \\
\text { None } \\
\text { Yes } \\
\text { None } \\
\text { Yes } \\
\text { None } \\
\text { None } \\
\text { None } \\
\text { None } \\
\text { Yes } \\
\text { Yes } \\
\text { None } \\
\text { Yes } \\
\text { Yes } \\
\text { None } \\
\text { None } \\
\text { Not traced } \\
\text { Yes } \\
\text { Yes }\end{array}$ \\
\hline
\end{tabular}

*On systemic steroids. 
Table II shows the results according to the chronicity of the disease. The "acute" cases are those in which the disease had begun within 8 weeks of the start of the trial, usually fairly suddenly, and these were expected to have a good prognosis for the attack whatever the treatment. The "chronic" cases had a poorer prognosis, the disease having started between 3 months and 4 years before the trial.

TABLE II

RESULTS OF TREATMENT ACCORDING TO CHRONICITY

\begin{tabular}{|c|c|c|c|c|c|c|c|c|c|}
\hline \multirow{3}{*}{$\begin{array}{c}\text { Type } \\
\text { of } \\
\text { Attack }\end{array}$} & \multirow{3}{*}{$\begin{array}{l}\text { Total } \\
\text { No. of } \\
\text { Cases }\end{array}$} & \multicolumn{8}{|c|}{ Results of Treatment } \\
\hline & & \multicolumn{2}{|c|}{ Cleared } & \multicolumn{2}{|c|}{ Much Improved } & \multicolumn{2}{|c|}{ Improved } & \multicolumn{2}{|c|}{ No Change } \\
\hline & & No. & $\%$ & No. & $\%$ & No. & $\%$ & No. & $\%$ \\
\hline Acute & 20 & 3 & 15 & 6 & 35 & 9 & 45 & 2 & 10 \\
\hline Chronic & 10 & 0 & $\mathbf{0}$ & 1 & 10 & 6 & 60 & 3 & 30 \\
\hline Total & 30 & 3 & 10 & 7 & 23 & 15 & 50 & 5 & 17 \\
\hline
\end{tabular}

These Tables show that the results depend very much on the duration of the disease before treatment. The relapse rate emphasizes this distinction, as in the acute group only five out of eighteen relapsed in contrast to four out of six in the chronic group.

There was no noticeable difference in response between the juxta-papillary cases and those with an active focus elsewhere; the two cases in which no focus could be seen because of vitreous haze improved on Spiramycin but the disease was still active in both of these over a year later.

The result of the initial toxoplasmosis dye test varied between 1:7 and $1: 380$ (mean 1:79). The final test varied between negative and 1:168 (mean $1: 58$ ). In Table III the results of treatment are classified according as the dye test titre rose, diminished, or was unchanged after the 6-week course.

TABLE III

RESULTS OF TREATMENT ACCORDING TO CHANGE IN DYE TEST TITRE

\begin{tabular}{l|c|c|c|c}
\hline $\begin{array}{c}\text { Results of } \\
\text { Treatment }\end{array}$ & Rising & Diminishing & No Change & $\begin{array}{c}\text { Total No. of } \\
\text { Cases }\end{array}$ \\
\cline { 2 - 5 } Cleared & 2 & 1 & 0 & 3 \\
\hline Much Improved & 2 & 4 & 1 & 7 \\
\hline Improved & 5 & 9 & 1 & 15 \\
\hline No Change & 1 & 3 & 1 & 5 \\
\hline Total & 10 & 17 & 3 & 30 \\
\hline
\end{tabular}


Although the numbers are small they seem to indicate that changes in the clinical picture are not necessarily parallelled one way or another by a change in the dye test titre over a 6-week period.

The initial toxoplasmosis complement-fixation test was positive in six cases; after 6 weeks four cases were still positive, two had become negative, and three others had become positive. There was no correlation between the changes in the complement-fixation test and the clinical state.

Toxic side-effects were unimportant in this trial. Four patients had a little looseness of the bowels for the first week or so, but this was easily managed with the kaolin mixture. Two had transient anorexia and nausea. In only two was the dose of Spiramycin reduced-one because of anorexia and puffiness of the eyelids and the other because of diarrhoea; both patients became symptomless on the lowered dose.

\section{Discussion}

The results of this trial give little support for the statement that Spiramycin is the treatment of choice in ocular toxoplasmosis. Most of the improvement that occurred can be accounted for by the natural tendency of an attack to remit. This is especially true of those that start acutely with a local lesion and which are probably associated with the rupture of Toxoplasma cysts. The more chronic type of case which may be associated with active multiplication of the organisms in the retina has a poorer prognosis and in this trial such cases did badly. Several patients were put on systemic steroids and this alone would have brought about a remission in some of them. If the results of the follow-up period are included, then the ineffectiveness of Spiramycin is even more clearly demonstrated.

Chodos and Habegger-Chodos (1961) stated that they had good results with Spiramycin in posterior uveitis. However, their paper has been criticized by Kaufman (1961), who pointed out that the experimental rationale for the use of Spiramycin in toxoplasmosis is still uncertain. The trial by Chodos and Habegger-Chodos was uncontrolled and their criteria for the selection of patients are not clear. They state that "best results will be obtained in a fresh retinochoroidal lesion of toxoplasmic origin". But this type of case has a good prognosis in any event, and often clears in about 12 weeks without treatment. Finally, Chodos and Habegger-Chodos imply that, because they found Spiramycin to be effective in posterior uveitis and because it is lethal to Toxoplasma, cases of posterior uveitis which respond to Spiramycin are due to toxoplasmosis. A similar argument has been used by some authors with respect to Daraprim and sulphonamides in posterior uveitis. The argument is fallacious because Spiramycin, like sulphonamides and Daraprim given in combination, has a fairly wide spectrum of action and so might cause remission in any patient with an infectious type of uveitis. Therefore a therapeutic response is not necessarily an indicator of a specific action against toxoplasmosis. 


\section{Summary}

In this trial little evidence was found to support the statement that Spiramycin is the treatment of choice in ocular toxoplasmosis.

I wish to thank the surgeons of Moorfields Eye Hospital for allowing me to treat their patients, Prof. E. S. Perkins for his help and for suggesting that the trial be done, the Pathology Department, Institute of Ophthalmology, London for doing the pathological tests, and Dr. D. J. Lobascher and the staff of the Special Clinic which took part in this study.

\section{REFERENCES}

BogaCz, J. (1954). Bull. Soc. Path. exot., 47, 903.

Chodos, J. B., and Habegger-Chodos, H. E. (1961). Arch. Ophthal., 65, 401.

Hogan, M. J. (1958). Amer.J. Ophthal., 46, 467.

Kaufman, H. E. (1961). Arch. Ophthal., 66, 609.

Perkins, E. S. (1961). "Uveitis and Toxoplasmosis". Churchill, London. Smith, C. H., and Schofield, P. B. (1956). Brit. J. Ophthal., 40, 577.

Ryan, R. W., Hart, W. M., Culligan, J. J., Gunkel, R. D., JaCobS, L., and Cook, M. K. (1954). Trans. Amer. Acad. Ophthal. Otolaryng., 58, 867. 